NANAEKE

Indonesian Journal of Early Childhood Education

Volume 2, Nomor 2, Desember 2019

\title{
MANAJEMEN PENILAIAN PENDIDIKAN ANAK USIA DINI PADA SATUAN PAUD
}

\author{
Sitti Mania \\ Fakultas Tarbiyah dan Keguruan, UIN Alauddin Makassar \\ e-mail: sitti.mania@uin.alauddin.ac.id \\ Muhammad Rusydi Rasyid \\ Fakultas Tarbiyah dan Keguruan, UIN Alauddin Makassar \\ Email: Muhammad.rusydi@uin-alauddin.ac.id \\ Sri Mulyani \\ Jurusan Pendidikan Islam Anak Usia Dini \\ Fakultas Tarbiyah dan Keguruan, UIN Alauddin Makassar \\ e-mail: annymuhajir4@gmail.com \\ Ningsi Indasari \\ Jurusan Pendidikan Islam Anak Usia Dini \\ Fakultas Tarbiyah dan Keguruan, UIN Alauddin Makassar \\ e-mail: ningsi12@gmail.com \\ Wahyuni \\ Jurusan Pendidikan Islam Anak Usia Dini \\ Fakultas Tarbiyah dan Keguruan, UIN Alauddin Makassar \\ e-mail: unhiwahyuni57@gmail.com \\ Juliati \\ Jurusan Pendidikan Islam Anak Usia Dini \\ Fakultas Tarbiyah dan Keguruan, UIN Alauddin Makassar \\ e-mail: jj5203540@gmail.com
}

\begin{abstract}
Abstrak
Penelitian ini bertujuan untuk dapat mengetahui gambaran penerapan manajemen penilaian di TK Al-Aiqa Islamic School Kabupaten Gowa. Dalam penelitian ini digunakan penelitian kualitatif dengan dua subjek yaitu guru dan kepala sekolah. Data penelitian ini dikumpulkan melalui cara observasi, wawancara dan dokumentasi. Analisis data dilakukan dengan empat tahapan dimulai dengan pengumpulan data, reduksi data, penyajian data, dan penarikan kesimpulan atau verifikasi terhadap tahapan pengelolaan penilaian pada lokasi penelitian yang meliputi: perencanaan, pelaksanaan, pengolahan hasil belajar, pengarsipan dan pelaporan. Dalam perencanaan, TK Al-Aika Islamik School sebelum merancang tugas terlebih dahulu telah memiliki Rencana Pelaksanaan Pembelajaran Harian (RPPH) yang digunakan sebelum menyusun program kegiatan yang mendorong pertumbuhan dan perkembangan keterampilan, pengetahuan, sikap, dan fisik anak. Pelaksanaan penelitian terutama dilakukan berdasarkan deskripsi pertumbuhan
\end{abstract}


dan perkembangan individu anak. Deskripsi tersebut diperoleh melalui hasil pelaksanaan pembelajaran harian yang dilengkapi dengan alat dan kriteria penilaian, serta ketetapan indikasi capaiannya dalam waktu dan tempat yang telah ditentukan. Pengolahan hasil belajar dan pengarsifan dilakukan berupa kumpulan dari hasil penggabungan data anak dalam bentuk portofolio yang juga berfungsi sebagai bahan laporan perkembangan dan pertumbuhan peserta didik kepada orang tua mereka masing-masing.

Kata Kunci: Manajemen; Pendidikan Anak Usia Dini; Penilaian

\begin{abstract}
The aim of this study is to know the description of the application of management assessment in TK Al-Aiqa Islamic School, Gowa Regency. This study was a qualitative research with two subjects, teachers and principal of Tk Al-Aiqa Islamic School, Gowa Regency. The data were collected through observation, interviews and documentation and analyzed in four stages namely data collection, data reduction, data presentation, and withdrawal of a conclusion or verification.

The results showed that TK Al-Aiqa Islamic School had conducted evaluation through several stages, namely; planning, implementation or recording, processing of learning outcomes, archiving and reporting. In planning stages, TK Al-Aiqa Islamic School prepared questions based on Daily Learning Implementation Plan (RPPH). The implementation of assessments at TK Al-Aiqa Islamic School was conducted based on the description of the child's growth and development. The teachers prepared Daily Learning Implementation Plan, determined the assessment tools and criteria, and set the indicators of children's achievement in a certain time. Learning outcomes were archived and collected as the data of the children and made in form of portfolio that reported to parents.
\end{abstract}

Keywords: management; early childhood education programs; assessment

\title{
PENDAHULUAN
}

Pendididkan anak usia dini merupakan upaya yang bertujuan untuk membina anak mulai sejak lahir hingga usia enam tahun. Upaya tersebut dilakukan dengan cara memberikan rangsangan pendidikan untuk membantu pertumbuhan dan perkembangan jasmani dan rohani. Pndidikan anak usia dini membantu anak dalam mempersiapkan diri menuju jenjang pendidikan lanjut (Kemdukbud, 2015).

Perkembangan anak sangat dibutuhkan karena mampu mengacu perubahanperubahannya, baik itu perubahan biologis, psikologis, dan emosional anak. Perkembangan anak di pengaruhi oleh faktor lingkungan, perkembangan anak melalui pelatihan orang tua,faktor lainnya di pengaruhi dengan kualitas pelayanan. Perkembangan anak dipengaruhi oleh berbagai factor antara lain faktor lingkungan, pelatihan orangtua dan faktor yang dipengaruhi oleh kualitas pelayanan.

Pertumbuhan dan perkembangan PAUD yang sedemikian pesat tersebut tidak diimbangi dengan pola maanajemen yang profesional. Hal tersebut sesuai dengan yang dikemukakan dalam (Suyadi, 2011) bahwa banyak kalangan yang menyebut 
manajemen yang dijalankan di PAUD sebagai manajemen tukang cukur karena dikerja sebagai serabutan.

Manajemen pembelajaran PAUD adalah cara guru dalam merencanakan, melaksanakan proses pembelajaran dan mengevaluasi hasil pembelajaran, seperti yang dinyatakan dalam Permendikbud 137 Tahun 2014. Menurut Mulyasa (2012), penilaian merupakan suatu proses pengumpulan, pelaporan, penggunaan informasi tentang hasil belajar anak dalam menerapkan prinsip-prinsip penilaian, pelaksanaan berkelanjutan.

Manajemen penilaian PAUD adalah salah satu bagian yang penting yang dilakukan untuk mendukung terwujudnya manajemen PAUD yang profesional. Sebagai mana yang telah dikemukakan oleh Agustiningsih (2015) bahwa proses pembelajaran di TK tidak terlepas dari unsur penilaian, karena penilaian merupakan unsur penting dalam pembelajaran.

Azizah (2014) mengemukakan bahwa penilaian adalah serangkaian kegiatan untuk dapat meemeroleh, meganaalisis, menafsirkan data tentang proses dan hasil belajar siswa yang dilakukan secara sistematis. Mulyasa (2012) mengemukakan bahwa penilaian adalah suatu proses pengumpulan, pelaporan, dan penggunaan informasi tentang hasil belajar peserta didik dengan menerapkan prinsip-prinsip penilaian, pelaksanaan berkelanjutan, bukti autentik, akurat dan konsisten.

Penilaian Paud berfokus kepada perkembangan dan kemampuan belajar anak didik. Zahro (2015) menjelaskan bahwa penilaian dapat dilakukan dengan seluruh aspek perkembangan anak. Berdasarkan kurikulum 2013 PAUD meliputi; perkembangan nilai agama dan moral, perkembangan sosial dan emosional, perkembangan bahasa, perkembangan kogntif, perkembangan fisik dan motorik, dan perkembangan seni.

Adapun tujuan asesmen perkembangan anak usia dini menurut Suyadi (2016), yaitu untuk; (1) mendeteksi perkembangan dan arahan dalam melakukan penilaian diagnostik ketika terindikasi, yang meliputi deteksi tentang status kesehatan anak usia dini, kepekan indra, bahasa, motorik kasar dan motorik halus, dan perkembangan sosial emosional; (2) mengidentifikasi minat dan kebutuhan anak usia dini; (3) menggambarkan kemajuan perkembangan dan belajar anak usia dini; (4) mengembangkan kurikulum; (5) memperbaiki dan mengembangkan kegiatan pembelajaran yang sesuai dengan perkembangan dengan kebutuhan anak usia dini; dan (6) mengasesmen program dan lembaga akuntabilitas program dan lembaga.

TK Al-Aiqa Islamic School merupakan salah satu TK yang berada diwilayah kabupaten Gowa Sulawessi Selatan. Jumlah anak didik di sekolah mengalami penambahan dari tahun ketahun untuk tahun 2019 ini, jumlah anak didik berjumlah sekitar 28. Penelitian yang dilakukan bertujuan agar mengetahui gambaran penerapan manajemen penilaian di TK Al-Aiqa Islamic School Pallangga Kabupaten Gowa. 
Berdasarkan penelitian terdahulu Zahro (2015) penilaian adalah suatu proses pengumpulan informasi dari guru terhadap tingkat perkembangan dan pencapaian pembelajaran yang telah dilakukan oleh peserta didik dengan menggunakan berbagai tehnik yang dapat mengungkapkan, membuktikan, atau memperlihatkan dengan sesuai bahwa kemampuan yang telah diatur benar-benar sudah dikuasai dan dicapai oleh peserta didik.

Berdasarkan penelitian terdahulu Harun (2012) perencanaan program pendidikan disekolah secara umum telah tersusun dengan baik, hal ini dapat dilihat dari adanya perencanaan kegiatan pendidikan dalam menyusun perencanaan kegiatan yang sesuai dengan ketentuan yang diantaranya ialah perencanaan administrasi, pengajaran, guru, dan kurikulum. Wahyuni (2019) memaparkan beberapa langkah dalam tehnik penilaian yaitu dengan merumuskan penilaian, kemudian melakukan tehnik penilaian yang digunakan, setelah itu mengobservasi proses pembelajaran yang berlangsung, menilai hasil karya anak setelah itu pelaporan hasil belajar anak dan yang terakhir standar penilaian. Begitu pula dalam penelitian yang dilakukan oleh Damayanti, dkk (2018) penilaian anak usia dini dimulai dari tahap perencanaan, tahap pelaksanaan atau pencatatan, pengolahan hasil belajar, pengarsipan, dan sampai pada tahap pelaporan. Pelaporan ini dapat dikomunikasikan kepada orang tua anak didik melalui penerimaan raport maupun dalam pertemuan rutin serta face to face dengan orang tua anak.

\section{METODE PENELITIAN}

Jenis penelitian yang digunakan dalam penelitian ini adalah dengan metode kualitatif. Subjek yang digunakan dalam penelitian ini adalah guru dan kepala sekolah Tk Al Aiqa Islamic School yang beralamat di Perumahan Puri Pallangga Mas 2 Kabupaten Gowa. Teknik pengumpulan data melalui observasi, wawancara, dan dokumentasi. Fokus penilaian dalam penelitian ini dilakukan berdasarkan penilaian pada kurikulum penididikan anak usia dini yang dibagi menjadi lima tahap, yakni tahap perencanaan, tahap pelaksanaan atau pencacatan, pengolahan hasil belajar, pengarsipan, dan pelaporan. Adapun teknik analisis data yang dilakukan yaitu melalui empat tahap, pengumpalan data, reduksi data, penyajian data,dan penarikan kesimpulan atau pengumpulan verifikasi.

\section{HASIL DAN PEMBAHASAN}

Berdasarkan hasil penelitian yang dilakukan di TK Al Aiqa Islamic School di paparkan berdasarkan proses managmen penilaian paud yang terdapat pada kurikulum 2013 yakni tahap perencanaan tahap pelaksanaan dan tahap evaluasi.

\section{Perencanaan}


Hal pertama yang` dilakukan TK Al-Aiqa Islamic School adalah menentukan kompetensi dasar dan merumuskan kegiatan yang akan dilakukan dengan menyiapkan rencana pembelajaran harian(RPPH) sebelum membuat kegiatankegiatan seperti keterampilan, pengetahuan, sikap dan perekembangan bahasa anak. Kepala sekolah maupun guru-guru TK A dan TK B sudah memiliki cacatancacatan tersendiri baik itu cacatan harian secara kata-kata dan adapun catatan anecdote dan cheklist yang telah disedikan oleh Ketua Yayasan yang nantinya cacatan-cacatan tersebut akan diperlihatkan kepada para orang tua anak dan akan menjadi cacatan arsip sekolah.

Penilaian kedua yang dilakukan kepala sekolah dan guru adalah menetapkan alat dan kriteria penilaian. TK Al- Aiqa Islamic School menentukan penilaian mereka disesuAiqan dengan indikator yang telah dicantumkan di RPPH sesuai tingkat kemampuan dan usia anak.

Penilaian ketiga dilakukan dengan mengobservasi setiap rangkaian kegiatan anak sekolah dimulai saat pagi hari anak datang kesekolah, bermain menunggu jam kelas dimulai, kegiatan baris berbaris dipagi hari, circle time (kegiatan berdoa dan bernyanyi) dilanjutkan solat dhoha dan memasuki ruang kelas untuk belajar hingga aktivitas makan dan istirahat lalu kembali melanjutkan pembelajaran dikelas.

\section{Pelaksanaan}

Pada tahap pelaksanaan penilaian, teknik yang dilakukan peneliti yakni metode observasi, metode wawancara, berbagai penugasan dan unjuk kerja. Dalam observasi terdapat tiga cara yakni menggunakan catatan harian, catatan hasil karya anak, dan melalui beberapa kegiatan - kegiatan yang diberikan kepada anak didiknya.

Pendidik mengamati perkembangan anak baik itu perkembangan kognitif, motorik, sosial emosi, dan terutama perkembangan bahasa peserta didik. Pelaksanaan penilaian di Tk Al'aiqa islamic school berdasarkan hasil wawancara dari kami yang dimana pendidk sangat berperan penting dalam pengamatan perkembangan anak. Karna di Tk Al-Aiqa memiliki tiga orang pendidik maka masing -masing saling berbagi tugas, terdapat kepala sekolah, kemudian pendidik di kelas $A$ dan pendidik di kelas $B$, pendidik di kelas $A$ dan $B$ masing-masing fokus pada anak didik mereka dan kepala sekolah mengimbanginya. Namun dibalik itu semua para pendidik di Tk Al'aiqa islamic school tetap menjalin kerjasama dengan sangat baik dan kompak.

Perkembangan peserta didik dilihat dan diamati oleh pendidik dari beberapa aspek, aspek yang pertama yaitu perkembangan kognitif anak dinilai ketika anak cepat menanggapi arahan dari pendidik. Aspek yang kedua yaitu perkembangan motorik anak yang dinilai dari hasil-hasil kerja karya anak yang diberikan oleh pendidik. Aspek yang ketiga yaitu perkembangan sosial emosi anak yang dinilai ketika anak-anak sedang bermain atau melakukan kegiatan-kegiatan lain bersama 
temannya. Penilaian selanjutnya yaitu aspek perkembangan bahasa anak yang dinilai ketika anak berkomunikasi, berinteraksi dengan guru dan teman-temannya.

Beberapa aspek yang telah dijelaskan diatas itu adalah hasil-hasil penilaian guru terhadap peseta didiknya, semua penilaian itu ada yang dilakukan dengan cara diamati kemudian dimasukkan kedalam catatan penilaian harian yang telah disediakan oleh ketua yayasan. Dan penilaian tambahannya dilaporkan secara langsung oleh pendidik kepada orangtua peserta didik.

\section{Pengolahan Hasil Belajar}

Pengolahan hasil belajar yang di lakukan oleh AL- Aiqa Islamic School berdasarkan hasil wawancara dari kepala sekolah mengatakan bahwa menggabungkan data melalui hasil pengamatan yang ditulis dalam catatan milik kepala sekolah yang memang disediakan oleh ketua yayasan. Begitupun dengan guru A dan guru B dan hasil karya anak dikumpulkan di map-map yang disediakan pula. Peneliti melakukan wawancara dengan guru kelompok B terkait strategi dalam membantu anak didik mencapai tingkat pertumbuhan dan perkembangan. Berdasarkan hasil wawancara tersebut guru-guru melakukan pemberian tugas secara bertahap dari belum bisa, kurang bisa hingga akhirnya bisa mengerjakan tugas dengan mandiri.

\section{Pengarsipan}

Kepala sekolah, guru TK A dan guru TK B melakukan pengarsipan yang merupakan pengumpulan dari hasil data-data serta cacatan catatan yang telah

dirangkum. Setiap anak masing-masing memiliki cacatan tersendiri dari masing masing pendidik baik TK A dan pendidik TK B, di tambah dengan catatan yang dimiliki oleh kepala sekolah . meskipun setiap kegiatan yang mereka lakukan sama, tetap diarsipkan dalam catatan karena penilaian dilakukan setiap harinya, perkembangan anak selalu di pantau dan dilaporkan kepada orang tua dan peserta didik. Setelah itu kepala sekolah selalu melakukan analisis data untuk memperoleh akhir perkembangan anak yang berdasarkan indikator yang telah ditetapkan begitupun denga guru TK A dan guru TK $B$.

\section{Pelaporan Hasil Belajar Anak}

Kepala sekolah guru TK A dan TK B mereka selalu membuat pelaporan hasil belajar tentang pertumbuhan dan perkembangan peserta didik. Mereka membuat hasil laporan dari karya anak dan dibuatkan uraian singkat dari aspek perkembangan agama dan moral.

Laporan-laporan perkembangan yang diarsipkan tersebut didalmnya meliputi laaporan perkembangan aspek motorik anak misalnya ketika anak sedang bermain ular tangga. Kemudian laporan kedua tentang perkembangan anak dinilai dari ketika anak diberikan tugas menceritkan pengalaman dari bangun tidur sampai kesekolah. Kemudian laporan yang ketiga yaitu dari aspek perkembangan bahasa anak dilihat dari bagaimana anak berinteraksi kepada gur dan teman-temannya. Adapun laporan 
terakhir yaitu tentang perkembangan sosial emosi dilihat dari bagaimana anak mampu meminta maaf dan memaafkan ketika berbuat salah atau temannya melakukan kesalahan. Dari iraian diatas adalahisi laporan penilaian dari guru TK A dan TK B maupun kepala sekolah.

\section{SIMPULAN}

Kesimpulan dari penilaian ini menunjukkan bahwa TK Al- Aiqa Islamic School telah melakukan beberapa proses melalui beberapa tahap yaitu tahap perencanaan, pelaksanaa atau pencatatan, pengolahan hasil belajar, pengarsipan dan pelaporan. Sebelum itu TK Al- Aiqa Islamic School terlebih dahulu rencana pelaksaan pembelajaran harian (RPPH), nenetapkan alat dan kriteria penialain anak, menentukan indikator pencapaian kemampuana anak dengan waktu dan tempat yang tepat. Dalam pelaksanaan penilaian TK Islamic School mereka melakukan berdasarkan deskriptif perkembangan anak melalui beberapa metode. Kemudia dibuatkan pelaporan dan pengarsipan.

\section{DAFTAR PUSTAKA}

Damayanti, E., Hartika, A.S., Herawati, Lisna, Jannah, R., \& Pratiwi, S.I. (2018). Manajemen Penilaian Pendidikan Anak Usia Dini Pada Taman Kanak-Kanak Citra Samata Kabupaten Gowa. Nanaeke: Journal of Early Childhood Education, (1(1): 13-24.

Hartati, S. (2017). Pengembangan model Asesmen Pekembangan Taman KanakKanak DI DKI Jakarta. Jurnal Pendidikan Usia Dini, 11(1): 19-30.

Harun. (2012). Manajemen Pendididkan Paud Al- Fath Sabang. Jurnal Administrasi Pendidikan Program Pascasarjana Unsyiah, 1(2): 76-86.

Kusrahmadi, S.D. (2018). Pentingnya Pendidikan Karakter Anak usia dini Dalam Mewujudkan Warga Negara yang baik. Jurnal Universitas Negeri Jakarta, 8(1): 1-15.

Purwasih, Wahyu. (2018). Tekhnik Penilaian Unjuk Kerja dan Catatan Anekdot sebagai Upaya Pemantauan Perkembangan Anak di PAUD Aisyiyah cabang Kartasura Sukoharjo Jawa Tengah. Jurnal Warna, 2(2) :76-85.

Rohita dan Nurfadilah. (2017). Pelaksanaan Penilaian Pembelajaran Di Taman Kanak-Kanak (Deskriprif) pada taman kanak-kanak Jakarta, Jurnal Al Azhar Humaniora, 4(1): 53-62.

Salamah, U. (2018). Penjaminan Mutu Penilaian Pendidikan. Evaluasi: Jurnal Manajemen Pendidikan Islam. 2(1): 274-292. 
Suyadi. (2016). Perencanaan dan Asesmen Pada Anak Usia Dini di Daerah istimewa Yogyakarta. Jurnal IImiah Tumbuh Kembang Anak Usia Dini, 1(1): 65-74.

Zahro. (2015). Penilaian Dalam Pembelajaran Anak Usia Dini. Jurnal Program Studi Pendidikan Guru PAUD STKIP Siliwangi Bandung, 1 (1): 92-111.

142 NANAEKE - Indonesian Journal of Early Childhood Education, Vol. 2, No. 2, Desember 2019 